Takeda, K. (2014). The interpreter as traitor: Multilingualism in Guizi lai le (Devils on the Doorstep). Linguistica Antverpiensia, New Series. Themes in Translation Studies, 13, 93-111.

\title{
The interpreter as traitor: Multilingualism in Guizi lai le (Devils on the Doorstep) ${ }^{1}$
}

\section{Kayoko Takeda}

Rikkyo University

kayokotakeda@rikkyo.ac.jp

This paper discusses ways in which multilingualism is represented in an award-winning Chinese film, Guizi lai le, and its subtitling. Known as Devils on the Doorstep in English, the movie approaches its multilingual setting realistically: Chinese villagers speak in Chinese, Japanese soldiers in Japanese, and interpreters mediate their communication. In examining the Chinese, Japanese and English subtitles of the film, the study focuses on the different strategies used by the translators to represent multilingualism and to subtitle offensive language. The behavior and fate of the Chinese interpreter in the film is also explored, with special attention to the power interpreters possess for controlling and manipulating information and the notion of the interpreter as traitor and war criminal in the context of conflict. Findings of this research invite further investigation into how the audience views multilingualism in cinema and how the identity and loyalty of interpreters is depicted in war-themed movies. Collaborative work by researchers from different language and cultural backgrounds should also be encouraged.

\section{Introduction}

Multilingualism in movies is not a new phenomenon, as Gambier (2012, p. 46) and Şerban (2012, pp. 42-43), among others, point out. For instance, there have been over the past decades a number of Hollywood movies in which characters speak Japanese (to varying degrees): Tokyo Joe (1949) with Humphrey Bogart as a former bar owner returning to postwar Tokyo, The Teahouse of the August Moon (1956) with Marlon Brando playing an Okinawan interpreter, Lost in Translation (2003) in which the protagonist feels lost, among other things, in a Japanese interpreter's 'undertranslation' and Memoirs of a Geisha (2005) with Chinese actresses playing geisha in English and Japanese. Perhaps because of the higher visibility of multilingual cinema owing to the global network of distribution with diverse channels (theater, DVDs, online, etc.) and transnational production in the current movie industry (Nornes, 2007), researchers have been paying greater attention in recent years to issues of language and translation in movies with multilingual settings. Following pioneering studies on multilingualism and translation in fiction (e.g., Delabastita, 2002; Delabastita \& Grutman, 2005; Grutman, 1998), 
foci of such investigations include: in what ways a plurality of languages are represented in movies, how characters who speak 'foreign' languages are depicted, and what strategies are used to present multilingual movies to audiences in various language markets (e.g., Bleichenbacher, 2008; Cronin, 2009; O'Sullivan 2011; Şerban, 2012). The present paper contributes to the current discussion on multilingualism in cinema by examining the award-winning Chinese film, Guizi lai le to add new information and perspectives to a body of research that primarily deals with films originating in Hollywood and Europe.

Known as Devils on the Doorstep in English, Guizi lai le (literally, "Devils have come") is set in a Chinese village during the tail end and aftermath of World War II in 1945. Excepting the last twenty minutes of sheer horror, the film mainly depicts rather comical exchanges between Chinese locals and two captives under their custody: a Japanese soldier and a Chinese interpreter employed by the Japanese army. Unlike many Hollywood movies in which multilingualism is treated with 'replacement strategies' (Bleichenbacher, 2008), language contact in this film carries the appearance of authenticity: Japanese soldiers speak Japanese, Chinese characters use Chinese, and interpreters mediate communication between them. There are even a few English lines spoken by American soldiers towards the end. In other words, this is a multilingual movie with a realistic treatment of languages ('presence strategy' (Bleichenbacher, 2008)). In addition, the behavior and fate of the captured Chinese interpreter invites discussion on various issues faced by interpreters in war. This interpreter often takes great liberties to make things up in his renditions in order to avoid upsetting either party in the conflict and for his own survival: he moans over the curse of the hard work he put in to acquire Japanese language skills only to get captured and condemned by his own people, and he becomes a victim of postwar summary execution as a disgraceful hanjian (a traitor to China).

The aims of the present paper are twofold. One is to describe and analyze how the two languages, Chinese and Japanese, are used throughout the film and interpreting between them is handled in three different sets of subtitles, Chinese, Japanese and English; focusing on the technical aspects and the treatment of offensive language. The other is to examine how the Chinese interpreter is depicted in the movie by referring to the historical context of the story, the power of interpreters to control the information and the complex position of interpreters who sometimes work against their own people in war and conflict.

This study first presents a synopsis of Guizi lai le and its three DVD editions used for the analysis. It then examines some technical, linguistic and cultural characteristics of the subtitles, followed by discussion on the portrayal of the Chinese interpreter. To conclude, the issues raised through the present paper are summarized and directions of future research are suggested. 


\section{Guizi lai le, Devils on the Doorstep, and Oni-ga Kita}

\subsection{Synopsis and reception}

Set in a village in Japanese-occupied northern China, the story of Guizi lai le starts one night in January 1945 with a mysterious man dumping two sacks at Ma Dasan's doorstep and telling Ma, a local peasant, to keep them until he returns. In the sacks are a wounded Japanese soldier, Hanaya Kosaburo, and a Chinese interpreter, Dong Hanchen, working for the Japanese army. The man never comes back. Ma and the villagers end up attending to the two captives for a long time. Hanaya fails to kill himself, be killed or escape, Dong mediates manipulatively, and $\mathrm{Ma}$ struggles with the fear of being killed or of killing. These circumstances produce a somewhat amicable relationship between Hanaya and the villagers. Hanaya suggests the villagers return him to the Japanese troops with a promise of food in exchange. Though Captain Sakatsuka violently reprimands Hanaya for coming back alive after being taken as a prisoner of war, he honors Hanaya's promise and holds a banquet for the villagers with his soldiers. In the middle of the feast, the behavior of some of the villagers irritates Sakatsuka, and he orders his men to slaughter them. All of a sudden, celebration turns into massacre and the village is completely destroyed. As Hanaya tries to commit suicide, Sakatsuka informs him of the end of the war. In the aftermath, Dong is shot to death as a hanjian. Meanwhile, in revenge, Ma attacks the Japanese soldiers, who are now detained by the Chinese army. A Kuomintang commander calls Ma a disgrace and orders a Japanese soldier to execute him in public. Ironically, it is Hanaya who beheads Ma.

A working version of Guizi lai le premiered at the Cannes Film Festival in 2000 and won the Jury Grand Prix. The Chinese government banned the film from showing in China (Hajari, 2000). Director Jiang Wen was also banned from directing films for five years (Silbergeld, 2008). Reported reasons include: that Jiang submitted Guizi lai le to the Cannes competition without the Chinese government's permission; that the movie is too sympathetic to the Japanese soldiers; and that the movie depicts villagers as too passive and ignorant, going against the Chinese narrative of its victory in resisting the Japanese (e.g., Gries, 2004; Hajari, 2000; Jiang \& Kawamoto, 2002; Silbergeld, 2008). Subsequently, a shortened final version was shown in theaters internationally. Critically acclaimed, Guizi lai le fetched five more international prizes after Cannes. 


\subsection{Three DVDs examined}

The present paper examines the subtitles included in three DVD editions of Guizi lai le: Japanese, American and Chinese. The Japanese edition was released with Japanese subtitles by Geneon in 2002, and the US edition with English subtitles by Homevision Entertainment in 2005. The Chinese edition, released by Guangzhou Audio-Visual Publishing House, was acquired by the author through a Japanese online shopping site for Chinese books and DVDs in 2012 but does not carry any information on the year of its release. It has Chinese, English, Japanese and Korean subtitles. The Japanese and the English subtitles in the Chinese edition are identical to those in the Japanese and US editions, respectively. The names of the English subtitler and the French subtitler are included in the original film credits. From the start of the project, Jiang Wen was aiming at the Cannes competition (Hajari, 2000; Kagawa, 2002). The English and French subtitles were probably prepared as part of the production process. The names of the Japanese subtitler and subtitle editor ${ }^{2}$ are shown at the end of the movie in the Japanese DVD. The Chinese DVD does not carry the names of its Japanese or Chinese subtitlers. It should be noted that: the cover of the US version shows "devils on the doorstep" as the title; the cover of the Japanese version presents "Oni-ga Kita!" (in Japanese characters; literally "Demons have come!") as the title, but also includes the original title, "Guizi lai le" (in Chinese characters), and the English title, "DEVILS ON THE DOORSTEPS"; and the cover of the Chinese version carries the original title, "Guizi lai le" (in Chinese characters), accompanied by an English title, "DURING THAT WAR", despite the fact that the English subtitle for the title within the movie says "DEVILS ON THE DOORSTEP”.

It seems important to explain the Chinese word "guizi (鬼子)" at this point. Generally translated as "devil" or "demon" in English, it is a pejorative term for foreigners and has been used, since the Japanese aggression in China, to insult the Japanese and express hatred against them. The word “oni (鬼)" in the Japanese title is usually translated as "demon" or "ogre" in English, but actually refers to supernatural creatures in Japanese folklore that symbolize something invincible, evil, or to be feared. Since it does not necessarily have wholly negative connotations, the Japanese title, accompanied by an exclamation mark, could project something light and amusing, in contrast with the Chinese title which clearly refers to the hated Japanese. ${ }^{3}$ Jiang Wen acknowledges in his interview that some people were concerned about the word 'devil' being too strong (Hajari, ibid.). Such concern might have been a reason the distributor of the Chinese DVD decided to use a devil-less, vague title in English, "DURING THAT WAR," on the cover. 


\subsection{Script translation and casting}

Director Jiang Wen seems to have pursued a realistic depiction of the film's wartime setting, having studied the looks and behavior of Japanese soldiers among other things (Jiang, 2000/2005). Primarily shot in black and white, the film has a feel of old war movies. Jiang cast Japanese actors for Japanese characters and Chinese actors for Chinese characters ("self-representative casting" (Shohat \& Stam, 1994, pp. 189-191)). Loosely based on a novel, the screenplay was co-written by Jiang and three other writers. According to Teruyuki Kagawa (2002), the Japanese actor who played Hanaya, Jiang kept rewriting the script almost daily as he shot the film. Two Japanese student actors who had parts in the movie translated the updated script into Japanese on-site. When Japanese dialogues translated from the Chinese script sounded unnatural to Japanese actors, they challenged Jiang and resolved the issues (Kagawa, 2002). It seems that effort was made to achieve "linguistic selfrepresentation" (Shohat \& Stam, 1994, pp. 191-194), giving "equal prominence" (Delabastita \& Grutman, 2005, p. 16) to both Chinese and Japanese.

Interestingly, Yuan Ding, who played Dong Hanchen (the Chinese interpreter), also acted as a real-life interpreter between the Japanese cast and Jiang Wen and his Chinese staff on the set, along with the abovementioned Japanese actors/translators and other bilingual staff (Kagawa, 2002). In a way, the representation of multilingualism in Guizi lai le is as authentic as it can be, having Japanese natives speaking Japanese, Chinese natives speaking Chinese, and a Chinese-Japanese bilingual playing an interpreter. As the realistic language treatment was consistently carried out throughout the movie, it can be considered a full implementation of 'vehicular matching' (Sternberg, 1981). There is no trace of 'replacement strategy' (Bleichenbacher, 2008), which can be found in many mainstream movies such as The Last Emperor (1987), in which Chinese and Japanese characters speak English almost exclusively.

\section{Subtitles}

As mentioned earlier, Guizi lai le resorts to subtitles, instead of dubbing, to deal with multilingualism within the film and for its distribution in different language markets. The use of subtitles over dubbing or other types of audiovisual translation may be attributed to various factors such as practices in a particular market ${ }^{5}$ and the audience's preference in a particular genre ${ }^{6}$. In the case of Guizi lai le, however, the most important reason for opting for subtitles probably derives from the realistic treatment of languages and the significant role the interpreter plays in the movie. As O'Sullivan (2011, pp. 180-188) suggests, the use of dubbing can erode multilingualism in cinema due to the reductive use of a single 
language. If dubbing were used in Guizi lai le, it would be difficult to project the same tension and confusion Hanaya and the villagers exhibit for not understanding each other and being at the mercy of the interpreter. Above all, it is highly doubtful if dubbing in a single language can accommodate the interpreter-mediated dialogues, which naturally occur across at least two languages. It simply would not support the narrative coherence of the movie.

In what follows, some characteristics of the Japanese, American and Chinese DVD subtitling of Guizi lai le are discussed. The focus is on the technical aspects involved in handling a plurality of languages and on how derogatory terms are translated in the three sets of subtitles.

\subsection{Technical aspects of subtitles in Guizi lai le}

There is a practice of providing Chinese subtitles for Chinese films in Chinese-speaking markets. Gambier (2012, p. 49) refers to two main purposes for intralingual subtitling (also known as captions or same language subtitling): one for language learning and the other for accessibility (for the deaf and hard of hearing). In the case of Chinese films, the customary practice of displaying almost verbatim what is said on screen presumably originated as an educational tool to promote literacy and aid people who speak different varieties of Chinese ${ }^{7}$ from the Chinese spoken in a given film (Curtin, 2007, p. 71). Accordingly, in the Chinese DVD of Guizi lai le as well, Chinese subtitles are provided not only for the Japanese and English dialogues (interlingual subtitling) but also for the Chinese dialogues (intralingual subtitling). Chinese subtitles are provided throughout the movie, except in some instances where the interpreter delivers a faithful interpretation from Chinese into Japanese (presumably in order to avoid redundancy) and when he engages in whisper interpreting. There is nothing to indicate (such as by the use of italics, quotation marks or parentheses) if a given subtitle is the verbatim rendition of a Chinese line or a translation of a Japanese line. It is assumed that such indications are unnecessary for Chinese-speaking audiences to make the distinction.

In the professional practice of Japanese subtitling, it is generally understood that Japanese subtitles should be limited to two lines, with at most 13 characters on one line, four characters per second, and a wellbalanced mix of the three different types of script (hiragana, katakana and kanji) for readability (Sato et al., 2003). All non-Japanese lines in the movie are accompanied by Japanese subtitles, except when the Chinese interpreter translates Japanese into Chinese faithfully, presumably to avoid redundancy - the Japanese subtitle for the interpreter's rendition would simply be a repeat of what the Japanese speaker had said. In the scene where villagers interrogate the two captives, the Chinese interpreter frequently shifts his 'footing' (Goffman, 1981) by delivering 
interpretation into Chinese and speaking for himself alternately. Here, the Japanese subtitles for the interpretations (whether faithful or not) are presented in parentheses in order to distinguish them from those for the interpreter's own utterances, which are presented without parentheses. In the English version, the subtitles for Japanese dialogues are in italics so that they can be differentiated from those for Chinese, which are not italicized. No English subtitles are provided in several instances where the interpreter gives faithful renditions or engages in whisper interpreting.

The reason the Japanese subtitles use parentheses to indicate translations in the above-mentioned scene is attributed to characteristics of the Japanese language. Unlike the current professional practice of using the first person in interpreting, the Chinese interpreter in this interrogation scene uses the third person, such as "He's new to China," and "He begs not to kill him," instead of "I'm new to China," and "I beg you not to kill me". Since the English subtitles keep the "he" used in the Chinese source speech, it is clear for the audience that those lines are meant to be "translation", not the interpreter's own remarks. In contrast, "he" is missing in the Japanese subtitles. This is because the grammatical subject is often omitted in a Japanese sentence, and the missing subject is even more common in Japanese subtitles due to the spatial constraint. The examples above would read "new to China" and "beg not to kill" in Japanese subtitles. Hence, the need for something (such as parentheses) to differentiate the interpreter's renditions from his own speech arises.

The redundancy issue of translating the interpreter's faithful renditions in subtitles is rather obvious. Unlike "diegetic interpreting" (O'Sullivan, 2011, pp. 80-93) in which interpreting is utilized without subtitles partly for storytelling for the audience and the effect of "suspense" (O’Sullivan, 2011, pp. 85-87) (see Shogun, 1980, for example), interpreter-mediated communication is presented in Guizi lai le in such a way that the audience understands the source speech (as is or with subtitles). Therefore, subtitles for interpretations will be repetitions that may place an unnecessary cognitive burden on the audience if they are faithful renditions of the source speech. Since subtitles are consistently provided for intentional mistranslations and the interpreter's own remarks in Guizi lai le, the audience would probably assume that no subtitle means accurate translation.

\subsection{Subtitles of offensive language in Guizi lai le}

Reduction, condensation and omission are often discussed as common strategies to deal with spatial and temporal constraints in subtitling (e.g., Díaz Cintas \& Remael, 2007; Georgakopoulou, 2009). In addition, due to the cross-modal transfer from the spoken to the written, accents and other individual speech traits tend to be "neutralized" (Díaz Cintas, 2010, p. 346) in subtitles. In particular, foul language such as swearing and racial 
slurs tends to become the target of deletion or "sanitization" because of "the tacit belief that they are more offensive when starkly reproduced in text than when verbalized" (Díaz Cintas, 2010, p. 346). Díaz Cintas and Remael (2007, pp. 195-200) point out, however, that the translation of swearing and taboo language is important when they contribute to the characterization and thematization of a given film.

Against the backdrop of military operations and asymmetric power relations between the occupier and the occupied, swearwords and other offensive language abound in Guizi lai le. They are key indicators of the hostile perception the Chinese held of the Japanese as well as the arrogance and rudeness of the Japanese soldiers. Depending on how such indicators are represented in subtitles, a Chinese-reading audience, a Japanese-reading audience and an English-reading audience may develop different impressions of the characters and setting in the movie. A corpusbased comprehensive analysis of swearword subtitling or an extensive experiment of audience reception is beyond the scope of the present research. However, it should be noted here that cross-cultural namecalling is present in varying degrees in the different sets of subtitles.

First of all, translating words that insult a particular nation or people into the language of that nation or people is problematic. For instance, Chinese characters in Guizi lai le consistently use pejorative terms (日本子 or 日本鬼子; literally “Japanese devil”) to refer to Japanese soldiers throughout the movie. They are translated as "Jap(s)" in English subtitles, but the corresponding Japanese subtitles have nothing to signify the derogatory tone. They simply say Japanese (日本人) or Japanese soldiers (日本兵). There are several possible reasons for this. First and foremost, there is not really a pejorative word to refer to Japanese in the Japanese language. Something explanatory could be added to indicate the harshness of the original language, such as "devillike Japanese” (鬼のような日本人), but it would be too wordy and hence too long for a subtitle. Other alternatives such as "shit-Japanese" (くそ日 本人), could be used, but the translator's self-censorship or censorship by the distributor may be imposed in order not to offend the Japanese audience. In fact, a glimpse of censorship in the Japanese subtitles can be detected in another scene in the movie, where Dong regrets having learned Japanese and says in Chinese that in his next life he wants to come back as a mute. The corresponding Japanese subtitle states, however, that he would not [learn] a foreign language in his next life. According to the Japanese subtitler (Terao, 2013), this modification is due to his own self-censorship out of consideration for 'the orally challenged': an explanatory alternative, “口の利けない人 (a person who cannot speak), would be too long for a subtitle.

Of course, subtitles are not the only venue for the audience to appreciate the attitudes and feelings held by the Chinese characters and Japanese soldiers towards one another. There is kinetic and paralinguistic information, such as gestures and facial expressions, available in the 
audiovisual medium. However, the untranslatability of the term the Chinese use to refer to Japanese soldiers leaves the audience unaware of its crudeness and force.

The Japanese soldiers also use pejorative terms to refer to China and the Chinese: 支那 (Shina) and ちゃんころ (chankoro). Since Shina originates in Chinese (Zhina) to refer to China, Chinese subtitles use the same word. Shina or Zhina used to be a neutral term, but it came to carry a derogatory tone during the Japanese aggression in China (Liu, 2009) and it retains that connotation today (Gottlieb, 2007). In English subtitles, it is simply translated as "China," since China has always been called by that name in English in modern history. The origin of chankoro is not clear, but it is a pejorative word used extensively by Japanese soldiers to refer to Chinese people. The Chinese and English subtitles seem to maintain the offensive tone of chankoro: it is mostly translated as 支那猪 ("Zhina pig(s)") in Chinese and as "Chinese pig(s)" or "mongrel(s)" in English. This may mean that Chinese-reading and English-reading audiences can be as cognizant as Japanese audiences of the Japanese troop's rudeness and arrogance in terms of their language use.

As previously mentioned, the relative 'cleanliness' of the Japanese subtitles could be explained by various factors: the 'spatiallychallenged' nature of the Japanese writing system with three sets of script $^{8}$, fewer standalone swearwords in Japanese ${ }^{9}$, and self- or othercensorship. It would be a difficult challenge for any Japanese subtitler to tackle profanity-filled Chinese dialogues in Guizi lai le. Any faithful renditions could attract excessive attention to the subtitles themselves due to their markedness, leaving the film itself in the background (see the case of the Japanese subtitles for Full Metal Jacket $(1987)^{10}$ ). On the other hand, English has a wider range of swearing lexis, and it may be better equipped to deal with Chinese profanity in a more flexible way. The frequently used "turtle fucker" (for 王八, which means a turtle and something like "bastard") is an example of a creative solution to translating terms deeply rooted in Chinese culture. In the end, the harshness of cross-cultural offensive language may be understood differently depending on which subtitles different audiences read.

\section{Multiple faces of the interpreter}

Interpreters in movies and fiction are often depicted as unreliable, manipulative, hybrid beings with double loyalties (e.g., Ben-Ari, 2010; Cronin, 2009; Kaindl, 2012; O'Sullivan, 2011). Dong Hanchen, the Chinese interpreter in Guizi lai le, may also fit into such a characterization. He invents translations, gives language lessons, and explains cultural differences in order to manage crises and ensure his own survival. These actions not only contribute to the comedic aspect of the story, but they also make the interpreter visible and bring issues of the 
interpreter's role and power to the fore. In fact, Dong is presented as more than a mere comedic or narrative vehicle for the movie. The audience can glean snippets of information from dialogues as to his family, educational and professional background and his thoughts on being an interpreter for the enemy. In other words, Guizi lai le portrays the interpreter with a human face, as a fairly developed character. This attentive representation of the interpreter may lead to the audience's cognizance of the historical context of Japanese occupation in China, the issues of interpreter loyalty in conflict, and the concept of interpreters as traitors and war criminals. The following sections focus on scenes and dialogues that epitomize those different traits of interpreters and discuss the significance of representing them in cinema.

\subsection{The interpreter as (mis)informer}

Early in the movie, there is a scene where an elder villager interrogates Hanaya and Dong. Dong tries hard not to create a hostile situation by begging for life and taking great liberties in altering Hanaya's rude and offensive utterances in his interpreting. In the table below, some relevant dialogues in this scene are shown with the source speech (Chinese or Japanese) with English translation (by the author) and its English subtitle. " $C$ " is the Chinese interrogator, " $H$ " is Hanaya, " $D$ " is Dong speaking for himself, and "I" is Dong's (assumed) interpretation.

Table 1: The interpreter's manipulative renditions

\begin{tabular}{|l|l|}
\hline Source speech (Chinese or Japanese) & English subtitles \\
\hline D: 饶命! [Spare my life!] & Don't kill us. \\
\hline-- ---- \\
\hline $\begin{array}{l}\text { H: 俺を撃て、殺せ } \\
\text { [Shoot me. Kill me.] }\end{array}$ & Shoot me. Kill me. \\
\hline $\begin{array}{l}\text { H: 勇気を出せよ臆病者 } \\
\text { [Be courageous, cowards.] }\end{array}$ & If you've got the guts. Cowards. \\
\hline $\begin{array}{l}\text { C: 这名儿咋这么长啊? 啥呀? [How } \\
\text { is this name so long? What?] }\end{array}$ & How come his name's so long? \\
\hline $\begin{array}{l}\text { D: よせよ 命が一番大切だから } \\
\text { [Stop it. To live is most important.] }\end{array}$ & Come on, we don't want to be killed. \\
\hline $\begin{array}{l}\text { C: 听不懂。变...变中国话 } \\
\text { [Don't understand. Change. Change } \\
\text { into Chinese.] }\end{array}$ & Chinese. \\
\hline
\end{tabular}




\begin{tabular}{|c|c|}
\hline $\begin{array}{l}\text { I: 他说他叫花屋小三郎, } 25 \text { 岁 [He } \\
\text { says his name is Kosaburo Hanaya, 25.] }\end{array}$ & His name is Kosaburo Hanaya. He's 25. \\
\hline $\begin{array}{l}\text { C: 杀过中国男人没? 糟蹋过中国女 } \\
\text { 人么? [Killed Chinese men? Raped } \\
\text { Chinese women? }\end{array}$ & $\begin{array}{l}\text { Has he killed Chinese men? Violated } \\
\text { Chinese women? }\end{array}$ \\
\hline $\begin{array}{l}\text { I: 中国の男を殺したことがあるか } \\
\text { 中国の女を犯したことがあるか } \\
\text { [Have you killed Chinese men? Have } \\
\text { you raped Chinese women?] }\end{array}$ & $\begin{array}{l}\text { Have you killed Chinese men? Raped } \\
\text { Chinese women? }\end{array}$ \\
\hline $\begin{array}{l}\text { H: 殺した 犯した その為にこそ } \\
\text { 支那に来たんだ [Killed. Raped. I } \\
\text { came to Shina for that.] }\end{array}$ & $\begin{array}{l}\text { Of course. That's what I came to China } \\
\text { for! }\end{array}$ \\
\hline $\begin{array}{l}\text { C: 他说他刚来中国 没见过中国女人 } \\
\text { / 没杀过中国男人 他是个做饭的 } \\
\text { [He says he just came to China, has } \\
\text { never seen Chinese women, never } \\
\text { killed a Chinese man. He is a cook.] }\end{array}$ & $\begin{array}{l}\text { He's new to China. Hasn't seen any } \\
\text { women yet. He's killed no one. He's a } \\
\text { cook. }\end{array}$ \\
\hline--- & --- \\
\hline H: 早くやれー [Do it quickly.] & Just do it. \\
\hline $\begin{array}{l}\text { I: 他说求求你们 别杀他! 拜托了! } \\
\text { [He begs you not to kill him! Please!] }\end{array}$ & He begs you not to kill him. \\
\hline--- & --- \\
\hline $\begin{array}{l}\text { D: 先别动手! 我还 有好多事情要 } \\
\text { 交代! [Hold on! I have a lot to say!] }\end{array}$ & Hold on! I've got more to say. \\
\hline $\begin{array}{l}\text { H: 俺を殺せ 俺は死を恐れん [Kill } \\
\text { me. I'm not afraid to die.] }\end{array}$ & Kill me! I'm not afraid to die! \\
\hline $\begin{array}{l}\text { I: 只有一只小隊 五挺机枪 [Only a } \\
\text { small unit, five machine guns.] }\end{array}$ & $\begin{array}{l}\text { It's a small unit! There are five machine } \\
\text { guns! }\end{array}$ \\
\hline $\begin{array}{l}\text { H: 大日本帝国陸軍は殺されても辱 } \\
\text { めはうけんぞー [The Japanese } \\
\text { Imperial Army may be killed, but will } \\
\text { never be humiliated.] }\end{array}$ & You can kill us, but never insult us! \\
\hline $\begin{array}{l}\text { I: 九台电话 两个话匣子 [Nine } \\
\text { telephones, two radios!] }\end{array}$ & $\begin{array}{l}\text { They have nine telephones, two radio sets } \\
\text { - }\end{array}$ \\
\hline $\begin{array}{l}\mathrm{H} \text { : 絶対に投降せん 絶対に祖国に } \\
\text { 背くか [Will never surrender. Will } \\
\text { never betray the homeland.] }\end{array}$ & $\begin{array}{l}\text { I'll never surrender! Or betray the } \\
\text { motherland! }\end{array}$ \\
\hline
\end{tabular}




\begin{tabular}{|l|l|}
\hline $\begin{array}{l}\text { I: 粮库一个 弹药库一个 [A grain } \\
\text { storage, an ammunition depot.] }\end{array}$ & An ammunition depot! \\
\hline $\begin{array}{l}\text { H: 皇軍は絶対に勝つ 天皇陛下万 } \\
\text { 歳 [The Imperial Army will surely win. } \\
\text { Long live the emperor!] }\end{array}$ & $\begin{array}{l}\text { We'll be victorious! Long live the } \\
\text { emperor! }\end{array}$ \\
\hline I: 还有十四匹马! [And 14 horses.] & - And 14 horses! \\
\hline H: 早く撃て一 [Shoot me quickly.] & - Shoot me! \\
\hline I: 交代完毕! [That's all.] & That's it. \\
\hline
\end{tabular}

Here, Dong hardly ever interprets what Hanaya says faithfully. He seldom interprets into Japanese what the Chinese elder says, either, since Hanaya is not interested in cooperating with his captors and keeps screaming at them, asking to be killed. Dong does not want to be killed. $\mathrm{He}$ is not a Japanese soldier taught to die if taken as prisoner of war. Dong's instinct for survival leads to a creative solution, which is to alter drastically what Hanaya says and volunteer some information on the Japanese troops in order to thwart the tension and give the captors the impression that he and Hanaya are harmless and cooperative.

Dong can control and manipulate the discourse because of his position in the middle as a mediator of communication between parties who do not understand each other's language. This is a classic case of Anderson's argument (1976) on the power the interpreter possesses by monopolizing the means of communication and controlling the discourse. This model, however, does not necessarily apply when a bilingual or bilinguals of the relevant languages are present in both parties, and the interpreter is aware that the accuracy of the interpretation can be checked. It should be noted that Dong acts like an obsequious, powerless servant of Captain Sakatsuka's once he and Hanaya return to the Japanese army base, as there is always someone who understands Chinese, however imperfectly, around Sakatsuka, and he is presumably scared of the repercussions of any noticed mistranslation, intentional or otherwise.

\subsection{The interpreter as (manipulative) language teacher and intercultural mediator}

While bound in captivity, Hanaya tells Dong to teach him the most insulting and offensive words in Chinese. Hanaya wants to enrage the villagers with those words so that they will kill him. Dong does not want to cause any trouble. He teaches Hanaya rather amusing, nonsensical phrases in Chinese, instead. When Ma and his lover come to feed Hanaya and Dong, Hanaya screams at them in Chinese: "Happy New Year, brother and sister-in-law! You're my granddad. I'm your son!" (English 
subtitles: ES, hereafter). Bewildered, they ask Dong why Hanaya sounds so angry when saying nice words. Dong explains: "Japs sound the same whether they're happy or angry. Why do you think we call them devils?" (ES). With Ma and his lover now smiling, Hanaya asks Dong why they are not angry. Dong explains: "The Japanese are always cursing them. They are used to it." (ES). Hanaya keeps shouting the phrases. Ma's lover asks Dong if he taught them to Hanaya. Dong says: "Yes. It's the spring festival. I taught him propitious phrases to thank you both." (ES). Ma appreciates Dong's 'thoughtfulness'.

Here again, Dong takes advantage of being the only one that fully understands the two languages. He is a deceiving language teacher and a manipulating cross-cultural adviser. Hanaya and $\mathrm{Ma}$ (and his lover) have no choice but to rely on Dong and take his words at face value in order to grasp the situation and communicate with each other. With the help of subtitles, the audience, just like the interpreter, can appreciate the comedy of these exchanges. The audience may also appreciate that Dong is not fooling $\mathrm{Ma}$ and Hanaya just for the sake of making fun of them. This is ingenuity for his own survival, ingenuity that carries him through to the end of the war.

\subsection{The interpreter as traitor}

In the aftermath of the war, Dong is brought into a place where spectators gather to watch criminals executed under the direction of a Kuomintang officer. With his face almost unrecognizable through torture, Dong gets shot to death as a hanjian who collaborated with the Japanese army. He seems to have known his fate. Some of his remarks throughout the movie suggest that he was fully aware of his problematic position. He moans over the curse of all the hard work he put into studying Japanese and wishes he were a mute. A son of a public official, Dong is from Manchuria in northeast China, which was ruled by the Japanese. He is an educated man in contrast with the peasant villagers and Hanaya who is also from a poor village in Japan. The movie does not directly show under what circumstances Dong became an employee of the Japanese army, but it does not seem that he was a willing participant.

Although interpreters in war and conflict did not attract much scholarly attention until recently, they have played significant roles throughout history in a range of fields, including intelligence gathering, military combats, cease-fire negotiations, postwar occupations and war crimes trials (e.g., Footitt \& Kelly, 2012; Inghilleri, 2012; Takeda, 2009, 2010). Within Cronin's framework (2006) of autonomous and heteronomous interpreters, Dong seems to be a typical heteronomous interpreter (a locally procured interpreter): he is the occupied who learns the occupier's language and works for the occupier using his language skills. In the time and place where Guizi lai le was set, the use of 
Japanese was mandated in government, military and school functions of Manchukuo, Japan's Manchurian puppet state which was established in 1932. Good command of Japanese was a gateway to a better job and more money (Shi, 2003). Dong may have been forced by the Japanese army to interpret for them or induced to do so with economic gains or pragmatic incentives. Either way, he was fully aware of the risk of being condemned by his own people as a traitor.

The Chinese concept of hanjian is unique in that it specifically refers to a Chinese person who betrays China by collaborating with an external force. During the Second Sino-Japanese War, the same person, possibly an interpreter, could be called a hanjian (traitor) in Chinese, a tainichi kyoryoku-sha (cooperator with Japan) in Japanese, and a collaborator in English. In postwar military trials in China a number of Japanese and Chinese interpreters who worked for the Japanese army were prosecuted and executed as war criminals (Hayashi, 2005). Of those, Chinese interpreters were also condemned as hanjian (ibid.).

Divided loyalties of interpreters have been depicted in multilingual cinema (e.g., Cronin, 2009; O'Sullivan, 2011). They are also a key issue discussed in the examination of interpreters in war (e.g., Takeda 2009, 2010). The dilemma interpreters face in working against people of their ethnic and cultural heritage in warring situations is not a main focus of Guizi lai le, however. Dong's priority in the midst of conflict is to stay alive. His behavior is always guided by how he could stay safe. Dong does not seem to feel conflicted or struggle with his sense of loyalty when he tells Sakatsuka to disregard the promise Hanaya made to the villagers or when he volunteers information on the Japanese troops to the villagers. He is an opportunist who sides with whoever has the power to keep him alive. Of course, this aspect of human nature may be found in people in the midst of life-threating, dire situations, yet interpreters may be more recognizable as traitors because they speak directly to locals the language of evil, oppression and tyranny on behalf of the ruler, occupier and invader. At the same time, being an interpreter can be empowering: an interpreter can exert his or her power to control the information and manipulate the discourse in order to protect the locals, if there are no other bilinguals. In Guizi lai le, however, this is not the case.

Although Guizi lai le takes a realistic approach to handling multilingual settings and even refers to the interpreter's background and emotions, it is not a movie that concentrates on the complexity of interpreting. Dong takes the foreground only when he speaks for himself or engages in manipulative translation. When he faithfully interprets in whisper or otherwise, he is an insignificant part of the scene. In other words, Dong is invisible when he does what he is supposed to do as an interpreter, and he becomes visible when he crosses that presumed boundary. It is not certain if such a depiction of interpreters would perpetuate the image of interpreters as unreliable and manipulative, but 
Guizi lai le may have succeeded in bringing to the attention of the audience the existence of interpreters in multilingual settings and the vulnerable position of heteronomous interpreters in war.

\section{Conclusion}

In her discussion of the aesthetics of multilingualism in cinema, Şerban (2011) suggests that communication and mediation issues observed in multilingualism are even more visible in film, which encourages the audience to reflect on interpreter-mediated events. Cronin (2009, p. 107) also discusses the audience's "reflexive awareness" of "the difficult and fraught process" of interpreting or language mediation by referring to the subtitles of Babel (2006). Further, O'Sullivan (2011) points out that double-presentation of diegetic interpreting and extradiegetic translation (subtitles) can highlight the mediating task of the interpreter.

Examination of Guizi lai le in the present paper reinforces this view of multilingualism in cinema as a rich opportunity for looking into various aspects of communication and mediation across languages and cultures. The film offers interesting objects for analysis, such as different strategies to represent a plurality of languages and renditions by the interpreter in subtitles, varying degrees of censorship (self- or otherwise) in translating derogatory terms in different languages, issues involving the power of interpreters to control and manipulate communication; the notion of interpreters as traitors, and the visibility and invisibility of interpreters.

It may be interesting to discuss, in future work, different approaches to multilingualism and translation in cinema in relation to expectations of the audience. It could be argued that the linguistic realism of Guizi lai le was pursued in line with expectations from the type of international audience the film was targeting, especially the Japanese. In contrast, movies in similar settings geared toward the Chinese domestic market, for instance, may give more prominence to the Chinese language and be less attentive to self-representative casting partly because the audience may not care much about linguistic authenticity (Takeda, 2005). As multilingualism in society and global film distribution develops further with an ever-increasing transnational flow of people, goods and information, audience expectations for the representation of multilingualism in cinema may be changing, possibly toward a more realistic approach, because of their greater exposure to communication across languages. Now that the spectators' voices are more immediate and accessible than ever via online media, it may be worthwhile to investigate audiences' views of multilingualism in movies, however partial they may be, and how filmmakers may be responding to them ${ }^{11}$.

Due to the author's limited proficiency in Chinese, the present paper did not engage in a fuller inquiry into linguistic features of the 
subtitle translation of Guizi lai le. Looking ahead, collaborative investigation by researchers from different linguistic and geographic backgrounds should be encouraged to produce a fresh and expanded inquiry into multilingualism in film. Also, research on interpreters as war collaborators may benefit from further examination of interpreters depicted in war-themed movies.

\section{References}

Anderson, R. B. W. (1976). Perspectives on the role of interpreter. In R. W. Brislin (Ed.), Translation: Application and research (pp. 208-228). New York, NY: Gardner.

Ben-Ari, N. (2010). Representations of translators of popular culture. Translation and Interpreting Studies, 5(2), 220-242.

Bleichenbacher, L. (2008). Multilingualism in the movies: Hollywood characters and their language choices. Tübingen: Francke.

Cronin, M. (2006). Translation and identity. London: Routledge.

Cronin, M. (2009). Translation goes to the movies. London: Routledge.

Curtin, M. (2007). Playing to the worlds' biggest audience: The globalization of Chinese film and TV. Berkeley, CA: University of California Press.

Delabastita, D. (2002). A great feast of languages: Shakespeare's bilingual comedy in King Henry V and the French translators. The Translator, 8(2), 303-340.

Delabastita, D., \& Grutman, R. (2005). Fictional representations of multilingualism and translation. Linguistica Antverpiensia (New Series), 4, 11-34.

Díaz Cintas, J. (2010). Subtitling. In Y. Gambier \& L. Van Doorslaer (Eds.), Handbook of translation studies, vol.1 (pp. 344-349). Amsterdam: John Benjamins.

Díaz Cintas, J., \& Remael, A. (2007). Audiovisual translation: Subtitling. Manchester: St. Jerome.

Footitt, H., \& Kelly, M. (2012). Languages at war: Policies and practices of language contacts in conflict. Basingstoke: Palgrave Macmillan.

Gambier, Y. (2012). The position of audiovisual translation studies. In C. Millán \& F. Bartrina (Eds.), The Routledge handbook of translation studies (pp. 45-59). London: Routledge.

Georgakopoulou, P. (2009). Subtitling for DVD industry. In J. Díaz-Cintas \& G. Anderman (Eds.), Audiovisual translation: Language transfer on screen (pp. 21-35). Basingstoke: Palgrave Macmillan.

Goffman, E. (1981). Forms of talk. Philadelphia, PA: University of Pennsylvania Press.

Gottlieb, N. (2007). Language and society. Cambridge: Cambridge University Press.

Gries, P. H. (2004). China's new nationalism: Pride, politics and diplomacy. Berkeley, CA: University of California Press.

Grutman, R. (1998). Multilingualism and translation. In M. Baker (Ed.), The Routledge handbook of translation studies (pp. 157-160). London: Routledge. 
Hajari, N. (2000, May 22). Devil's advocate. TIME, 155(20). Retrieved March 28, 2013.

http://edition.cnn.com/ASIANOW/time/magazine/2000/0522/cinema.jiangwe n.html

Harada, M. (1998, May). "Full Metal Jacket” jimaku tenmatsu-ki [Full Metal Jacket's subtitle story]. Chuokoron, 312-319.

Hayashi, H. (2005). BC-kyu Senpan Saiban [B/C-class War Crimes Trials]. Tokyo: Iwanami Shoten.

Inghilleri, M. (2012). Interpreting justice: Ethics, politics and language. London: Routledge.

Jiang, W. (2000/2005). Beyond questions of Chineseness: An interview with Jian Wen. Devils on the Doorstep (DVD). Homevision Entertainment.

Jiang, W., \& Kawamoto, S. (2002, June). Black humor-de tsukinukeru nicchu-no kabe [Breaking through the wall between China and Japan by black humor]. SEKAI, 236-242.

Kagawa, T. (2002). Chugoku miroku [China fascinating story]. Tokyo: KinemaJunposha.

Kaindl. K. (2012). Representation of translators and interpreters. In Y. Gambier \& L. Van Doorslaer (Eds.), Handbook of translation studies, vol. 3 (pp. 145-150). Amsterdam: John Benjamins.

Liu, L. H. (2009). The clash of empires: The invention of China in modern world making. Cambridge, MA: Harvard University Press.

Nornes, A. M. (2007). Cinema Babel: Translating global cinema. Minneapolis, MN: University of Minnesota Press.

O'Sullivan, C. (2011). Translating popular film. Basingstoke: Palgrave Macmillan.

Sato, I. et al. (2003). Eiga-jimaku nyumon [Introduction to film subtitling]. Tokyo: ALC.

Şerban, A. (2012). Translation as alchemy: The aesthetics of multilingualism in film. In R. Agost, P. Orero, \& E. Di Giovanni (Eds.), Multidisciplinarity in audiovisual translation (pp. 39-63). Special issue of MonTI, 4.

Shi, Gang (2003). Shokuminchi-shihai to Nihongo [Colonial rule and the Japanese language]. Tokyo: Sangensha.

Shinohara, Y. (2012). How can film subtitles meet an audience's expectations? Interpreting and Translation Studies, 12, 209-228.

Shohat, E., \& Stam, R. (1994). Unthinking Eurocentrism: Multiculturalism and the media. London: Routledge.

Silbergeld, J. (2008). Body in question: Image and illustration in two Chinese films by Director Jiang Wen. Princeton, NJ: Princeton University Press.

Sternberg, M. (1981). Polylingualism as reality and translation as mimesis. Poetics Today, 2(4), 221-239.

Takeda, K. (2009). War and interpreters. Across Languages and Cultures, 10(1), 4962.

Takeda, K. (2010). Interpreting the Tokyo War Crimes Tribunal. Ottawa, ON: University of Ottawa Press.

Takeda, M. (2005). Guizi-tachi no shozo: Chugokujin ga egaita nihonjin [Portrait of Guizi: Japanese depicted by Chinese]. Tokyo: Chuo-koron-sha. 
Terao, J. (2013). Email communication with the author. (April 2013).

Wetzel, P. J. (2004). Keigo in modern Japan: Polite language from Meiji to the present. Honolulu, HI: University of Hawaii Press.

\section{Filmography}

Bercovici, E., Chapman, B., Clavell, J., \& Feltham, K. (Producers), \& London, J. (Director). (1980). Shogun [TV miniseries]. United States: NBC.

Coppola, S., \& Katz, R. (Producers), \& Coppola, S. (Director). (2003). Lost in Translation [Motion picture]. United States: American Zoetrope \& Tohokushinsha Film.

Cummings, J. (Producer), \& Mann, D. (Director). (1956). The Teahouse of the August Moon [Motion picture]. United States: MGM.

Fisher, L., Wick, D., \& Spielberg, S. (Producers), \& Marshall, R. (Director). (2005). Memoirs of a Geisha [Motion picture]. United States \& China: Spyglass Entertainment, Amblin Entertainment \& Douglas Wick/Lucy Fisher.

Golin, S., Kilik, J., \& Inarritu, A. G. (Producers), \& Inarritu, A. G. (Director). (2006). Babel [Motion picture]. Summit Entertainment, Central Films \& Media Rights Capital.

Jiang, W., Dong, P., Yang, H., Liu, X., \& Liu, X. (Producers), \& Jiang, W. (Director). (2000). Guizi lai le [Motion picture]. China: Asian Union Film \& Entertainment Ltd., \& China Film Co-production Corporation.

Kubrick, S. (Producer), \& Kubrick, S. (Director). (1987). Full Metal Jacket [Motion picture]. United States \& United Kingdom: Harrier Films \& Natant.

Lord, R. (Producer), \& Heisler, S. (Director). (1949). Tokyo Joe [Motion picture]. United States: Columbia Pictures.

Thomas, J. (Producer), \& Bertolucci, B. (Director). (1987). The Last Emperor [Motion picture]. China, United Kingdom \& Italy: Recorded Picture Company, Hemdale Film Corporation, Yanco Films Limited, TAO Film, Screenframe, AAA Soprofilms \& Columbia Pictures.

1 The author extends heartfelt gratitude to Professors Noriyuki Tanino and Zinan Ye for their valuable input on the Chinese language, history and culture.

2 The Japanese subtitler, Jiro Terao, translated from the English and French subtitles and consulted with the editor who was an expert on Chinese cinema (Terao, 2013).

3 Given the overall tone of dark humor in the movie, the original title in Chinese seems to carry some humorous connotation as well. 
4 Shohat \& Stam (1994, p. 190) warns that self-representative casting is not sufficient to achieve a "community self-representation" if "narrative structure and cinematic strategies" are biased or distorted.

5 In the Japanese market, for example, out of 328 foreign films featured in theater in 2010, 289 had subtitles (88\%), 31 had subtitles and dubbing (9\%), and 8 had dubbing (3\%) (Shinohara, 2012, p. 209).

6 Nornes (2007, pp. 11-12) refers to a discussion on intellectuals' preference of subtitles for foreign (art) films in the United States.

7 Varieties/dialects of the Chinese language may not be mutually intelligible in their spoken form but share the same written form in general.

8 Chinese is considered a more concise language than Japanese, which uses a combination of a logographic writing system (kanji) and two sets of phonographic writing systems (hiragana and katakana).

9 Although there are ways to insult people by applying different levels of taigu-hyogen (expressions of consideration) in Japanese (Wetzel, 2004), it is generally understood that the Japanese language does not have many standalone swearwords.

10 Displeased with the original Japanese subtitles by a famous translator who did not fully present the profanity in the movie, director Stanley Kubrick had the subtitles redone. 'Abusive subtitling' (Nornes, 2007) with a lot of invented foul language in the second version attracted great attention from the Japanese media and audience (Harada, 1998).

11 Besides the political issues of Chinese actresses playing roles of Geisha, the representation of the Japanese culture and language caused major controversy among the Japanese audience of Memoirs of a Geisha (or Sayuri in Japanese) in 2005, for instance. 